\author{
А.А. Оприщенко ${ }^{1}$, С.Е. Золотухин ${ }^{1}$, Н.Н. Шпаченко ${ }^{1}$, А.А. Штутин ${ }^{1}$, И.В. Коктышев ${ }^{2}$ \\ 1Республиканский травматологический центр, Донецк \\ 2ГОО ВПО «Донецкий национальный медицинский университет имени М. Горького», Донецк
}

\title{
ОСОБЕННОСТИ РАННИХ ИММУНОЛОГИЧЕСКИХ РЕАКЦИЙ ПРИ ОСЛОЖНЕННОМ ТЕЧЕНИИ ОГНЕСТРЕЛЬНЫХ ПЕРЕЛОМОВ ГОЛЕНИ
}

В современных локальных военных конфликтах частота боевых повреждений конечностей составляет 53-70\% [1, 2]. Наибольшее число из них приходится на ранения нижних конечностей, в первую очередь голени. Они возникают преимущественно вследствие применения взрывных устройств и боеприпасов, характеризующихся значительным высокоэнергетическим разрушающим воздействием [1-4]. Боевые повреждения отличаются специфическими закономерностями общей реакции организма и локальными особенностями раневого процесса [1-7]. В патогенезе раннего периода травматической болезни расстройства иммунной системы играют важную роль, поскольку формируют различные осложнения, обусловленные инфекцией и недостаточной регенерацией поврежденных тканей $[1,5,6]$. Согласно современным представлениям выраженность и характер иммунного ответа при огнестрельных повреждениях может определять вероятность развития и тяжесть воспалительных осложнений, а также нарушений репаративной регенерации, в том числе торможение процессов остеогенеза $[1,6]$. Вследствие этого указанные осложнения являются предпосылкой развития огнестрельного остеомиелита, замедленной консолидации переломов и формирования ложных суставов, ортопедических деформаций конечности, что в свою очередь приводит к стойкой инвалидизации пациентов [1-7]. Иммунный ответ зависит от большого числа разнообразных факторов, в том числе специфичных для каждого конкретного театра военных действий - экологических и климатических условий региона, демографических характеристик, преморбидного фона, медико-тактических условий и многих других $[2,3,6]$. Вследствие этого можно предполагать наличие ряда особенностей иммунной реакции раненых, присущих нынешнему конфликту в Донбассе. В доступной литературе данный вопрос не освещался.

Целью исследования являлось изучение некоторых особенностей иммунного ответа в раннем периоде травматической болезни при осложненном течении огнестрельных переломов голени.

\section{МАТЕРИАЛ И МЕТОДЫ}

Проведено клинико-лабораторное обследование 83 раненых с огнестрельными переломами костей голени, находившихся на лечении в Республиканском травматологическом центре в период 2015-2017 гг. Согласно критериям включения в исследование отбирали раненых с огнестрельными переломами голени, являющимися доминирующим повреждением. При этом раненые, которым производились первичные ампутации, исключались, также в исследование не включали раненых, переведенных из других учреждений, срок более 24 ч от момента ранения. Все раненые были мужчины, средний

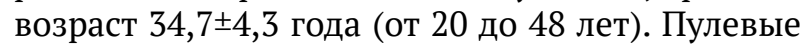
ранения имели место у 29 (34,9\%) пострадавших, взрывная травма - у $54(65,1 \%)$, в том числе осколочные - 47 (56,6\%), минно-взрывные - 7 (8,4\%). Изолированные повреждения сегментов опорно-двигательного аппарата установлены у 34 (40,9\%) раненых, множественные - 31 (37,4\%), сочетанные - 18 (21,7\%). Шок 2-3 степени имел место у 18 (21,7\%) раненых. Тяжесть повреждений конечностей оценивалась по шкале ВПХ-П (OP) и составила $3,2 \pm 0,3$ баллов [8]. Общая тяжесть повреждений $-4,1 \pm 0,2$ баллов. Сопутствующая терапевтическая патология была зафиксирована у 5 (6,0\%) человек - преимущественно хронические заболевания пищеварительного тракта и мочевыводящих путей. Средний срок доставки раненых в клинику составил 98,7士11,2 мин. (от 50 до 190). Открытые переломы IIIA типа по классификации Gustilo-Andersen [9, 10] были диагностированы в 34 (41,0\%) наблюденияХ, IIIB - 46 (55,4\%) случаях, IIIC - 3 (3,6\%).

(c) А.А. Оприщенко, С.Е. Золотухин, Н.Н. Шпаченко,

А.А. Штутин, И.В. Коктышев, 2019

(C) Университетская Клиника, 2019 
При поступлении все раненые обследовались стандартными физикальными и рентгенографическими методами, выполнялись общие клинические лабораторные и инструментальные исследования. В течение первых 12 часов пребывания в клинике все раненые были оперированы - производили первичную хирургическую обработку (ПХО) повреждений, туалет поверхностных и мелких непроникающих ран, различные виды специализированных вмешательств при множественных и сочетанных повреждениях. Во всех наблюдениях выполняли первичный остеосинтез переломов голени аппаратами внешней фиксации спице-стержневого или стержневого типа. Гемотрансфузии использовали у 48 (57,8\%) раненых.

На основании ретроспективного анализа результатов лечения материал историй болезней был разделен на две группы. У пострадавших первой группы $(\mathrm{n}=53)$ имел место неосложненный характер клинического течения и репаративного остеогенеза, у пострадавших второй $(\mathrm{n}=30)$ - осложненный (развитие ранних или поздних местных инфекционно-гнойных осложнений, нарушение консолидации переломов голени при технически правильном выполнении остеосинтеза). При этом следует отметить, что нарушение процесса остеогенеза ассоциировалось с наличием местных воспалительных осложнений. По возрасту, полу и характеру первичного повреждения пострадавшие в двух группах значимо не различались.

Методика иммунологического исследования. При изучении Т-клеточного звена иммунитета определяли общее количество Т-лимфоцитов (CD3+), Т-хелперов (CD3+ CD4+), цитотоксических Т-лимфоцитов (CD3+ CD8+) и Т-киллеров (CD3+ CD16+) в мкл. Для изучения В-клеточного звена иммунитета определяли общее количество В-лимфоцитов (CD3+ CD20+) в мкл крови [2]. Об активации клеток T- и В-лимфоцитов судили по антигенам, экспрессирующих молекулы активации: CD25+ (В-лимфоцитов); HLA-DR+ (Т-лимфоцитов), a также апоптоза (CD95+) [11, 12, 13]. Дополнительно вычисляли отношение abs CD4+ / abs $\mathrm{CD} 8+$ (иммунорегуляторный индекс). Концентрацию сывороточных иммуноглобулинов Ig A, Ig G, Ig M определяли методом иммунопреципитации в агаровом геле [14]. Для изучения неспецифической защиты организма применяли методику оценки фагоцитарного звена иммунной системы. В работе определяли поглотительную активность фагоцитирующих нейтрофильных гранулоцитов крови: фагоцитарный индекс (ФИ) - долю активно фагоцитирующих нейтрофильных гранулоцитов, выраженную в \%; фаго- цитарное число (ФЧ) - среднее число частиц, поглощенных одним фагоцитирующим нейтрофилом. В качестве тест-системы использовали частицы латекса диаметром 3 мкм [12, 14]. Уровень цитокинов (ИЛ-1, ИЛ-2, ИЛ-4, ИЛ-6, ИЛ-8, ИЛ-10, ФНО- $\alpha$ ) определяли в сыворотке крови методом иммуноферментного анализа (Elx 800, «Bio-tek instruments», США) с использованием тест-систем «ГосНИИ особо чистых биопрепаратов» (С.-Петербург) и «Протеиновый контур» (С.-Петербург). Исследования иммунологических показателей в раннем периоде проводили в первые сутки, на 3-й, 4-6-й, 7-14 дни травматической болезни (ТБ), а также через 3 месяца после ранения.

Результаты клинико-лабораторных исследований обработаны с помощью пакета статистических программ Statistica for Windows 6.0. Сравнение количественных параметров, представленных в формате среднее \pm ошибка репрезентативности $(\mathrm{M} \pm \mathrm{m})$, проводили методом Вилкоксона для сопряженных групп.

Во всех случаях было получено информированное согласие на проведение исследований, использование материалов лечения и исследований в научно-исследовательской работе и профессиональных публикациях. Данное исследование является фрагментом плановой НИР и одобрено местной комиссией по биоэтической экспертизе.

\section{РЕЗУЛЬТАТЫ И ОБСУЖДЕНИЕ}

При изучении особенностей иммунологических нарушений в раннем периоде травматической болезни у раненых с огнестрельными переломами костей голени были получены следующие результаты.

В таблице 1 представлено содержание антиген-положительных лимфоцитов периферической крови в контроле, а также с нормальной и осложненной консолидацией переломов.

До выполнения оперативного вмешательства показатели иммунограммы у всех пострадавших кроме CD16+-лимфоцитов (NK-клеток) не отличались от показателей контрольной группы людей. Абсолютное содержание NK-клеток у пациентов было снижено на $42,9 \%(\mathrm{p}<0,05)$. Такой состав иммунокомпетентных клеток указывал на процесс восстановления иммунитета и на слабое звено в этом восстановлении, которое приходилось на NK-клетки, как известно, наиболее чувствительных к действию глюкокортикоидных гормонов [7, 10].

Через 3 дня после операции у пострадавших первой подгруппы (с неосложненным типом клинического течения и остеогенеза в отдаленном периоде травмы) показатели иммунограм- 
Таблица 1.

Содержание антиген-положительных лимфоцитов периферической крови у пострадавших с нормальной и осложненной консолидацией переломов до и после операции $(\mathrm{M} \pm \mathrm{m})$

\begin{tabular}{|c|c|c|c|c|c|c|}
\hline \multirow{4}{*}{$\begin{array}{c}\text { Антиген- } \\
\text { положительные } \\
\text { клетки, ед. }\end{array}$} & \multirow{4}{*}{$\begin{array}{c}\text { Контроль } \\
(\mathrm{n}=15)\end{array}$} & \multicolumn{5}{|c|}{ По отношению к операции } \\
\hline & & \multirow{3}{*}{$\begin{array}{c}\text { до } \\
\text { операции }\end{array}$} & \multicolumn{4}{|c|}{ консолидация после операции } \\
\hline & & & \multicolumn{2}{|c|}{ через 3 дня } & \multicolumn{2}{|c|}{ через 3 месяца } \\
\hline & & & нормальная & осложненная & нормальная & осложненная \\
\hline CD3+, $\times 10^{9} /$ л & $1,22 \pm 0,08$ & $0,79 \pm 0,13$ & $0,96 \pm 0,12$ & $0,59 \pm 0,13^{*}$ & $1,13 \pm 0,08$ & $0,90 \pm 0,15$ \\
\hline $\mathrm{CD} 4+, \times 10^{9} /$ л & $0,71 \pm 0,05$ & $0,56 \pm 0,11$ & $0,67 \pm 0,08$ & $0,53 \pm 0,11$ & $0,71 \pm 0,09$ & $0,57 \pm 0,13$ \\
\hline CD8+, $\times 10^{9} / \pi$ & $0,39 \pm 0,06$ & $0,28 \pm 0,04$ & $0,31 \pm 0,09$ & $0,14 \pm 0,08^{*}$ & $0,37 \pm 0,10$ & $0,27 \pm 0,08$ \\
\hline $\mathrm{CD} 4+/ \mathrm{CD} 8+, \times 10^{9} /$ л & $1,82 \pm 0,2$ & $2,0 \pm 0,17$ & $2,2 \pm 0,18$ & $3,8 \pm 0,17$ & $1,9 \pm 0,17$ & $2,1 \pm 0,18$ \\
\hline $\mathrm{CD} 16+, \times 10^{9} /$ Л & $0,28 \pm 0,03$ & $0,16 \pm 0,05^{*}$ & $0,15 \pm 0,05^{*}$ & $0,13 \pm 0,04^{*}$ & $0,27 \pm 0,18$ & $0,14 \pm 0,03^{*}$ \\
\hline $\mathrm{CD} 20+, \times 10^{9} / \pi$ & $0,17 \pm 0,02$ & $0,18 \pm 0,04$ & $0,25 \pm 0,04^{*}$ & $0,14 \pm 0,02$ & $0,21 \pm 0,03$ & $0,17 \pm 0,02$ \\
\hline
\end{tabular}

Примечание: * - обозначена статистическая значимость различий при сравнении с группой контроля $(\mathrm{p}<0,05)$.

Таблица 2.

Функциональная активность лимфоцитов и нейтрофилов периферической крови у пострадавших с нормальной и осложненной консолидацией переломов до и после операции $(\mathrm{M} \pm \mathrm{m})$

По отношению к операции

\begin{tabular}{|c|c|c|c|c|c|c|}
\hline \multirow{3}{*}{$\begin{array}{c}\text { Антиген- } \\
\text { положительные } \\
\text { клетки, ед. }\end{array}$} & \multirow{3}{*}{$\begin{array}{c}\text { Контроль } \\
(\mathrm{n}=15)\end{array}$} & \multirow{3}{*}{$\begin{array}{c}\text { до } \\
\text { операции }\end{array}$} & \multicolumn{4}{|c|}{ консолидация после операции } \\
\hline & & & \multicolumn{2}{|c|}{ через 3 дня } & \multicolumn{2}{|c|}{ через 3 месяца } \\
\hline & & & нормальная & осложненная & нормальная & осложненная \\
\hline $\mathrm{CD} 25+, \times 10^{9} /$ л & $0,15 \pm 0,03$ & $0,08 \pm 0,03^{*}$ & $0,13 \pm 0,04$ & $0,08 \pm 0,03^{*}$ & $0,15 \pm 0,03$ & $0,10 \pm 0,02$ \\
\hline $\mathrm{CD} 95+, \times 10^{9} / \pi$ & $0,14 \pm 0,02$ & $0,16 \pm 0,04$ & $0,31 \pm 0,05^{*}$ & $0,32 \pm 0,05^{*}$ & $0,14 \pm 0,02$ & $0,22 \pm 0,05^{*}$ \\
\hline HLA DR+, $\times 10^{9} / \pi$ & $0,24 \pm 0,04$ & $0,17 \pm 0,03$ & $0,30 \pm 0,07$ & $0,15 \pm 0,02 *$ & $0,21 \pm 0,04$ & $0,22 \pm 0,03$ \\
\hline ФИ, \% & $58,2 \pm 1,5$ & $58,2 \pm 2,3$ & $59,6 \pm 2,5$ & $52,6 \pm 2,7$ & $59,9 \pm 1,9$ & $54,8 \pm 2,3$ \\
\hline ФЧ, ед. & $2,720,33$ & $2,4 \pm 0,05$ & $2,8 \pm 0,03$ & $2,0 \pm 0,03^{*}$ & $2,7 \pm 0,2$ & $2,3 \pm 0,04$ \\
\hline
\end{tabular}

Примечание: * - обозначена значимость различий по сравнению с контролем (p<0,05).

мы, за исключением CD16+ и CD20+-клеток, от данных контрольной группы людей не отличались. Показатели CD20+ (В-лимфоцитов) превышали значения контроля на $47,1 \%(\mathrm{p}<0,05)$. Такое увеличение содержания В-лимфоцитов свидетельствовало об активации и начального процесса антителогенеза. У пациентов с осложненным типом консолидации переломов в этом периоде имело место снижение абсолютного количества CD3+-клеток (Т-лимфоцитов), в том числе CD8+-клеток (цитотоксических лимфоцитов) и CD16+-клеток. Эти показатели были снижены на 51,6\%, 64,1\% и 53,6\% соответственно.
Обращало внимание то, что абсолютное число В-лимфоцитов не увеличивалось, как у пострадавших первой группы.

Через 3 месяца после операции у пациентов с нормальной консолидацией переломов не было отклонений иммунологических показателей от показателей контрольной группы людей. У пациентов с осложненным типом также имелась тенденция к восстановлению числа иммунокомпетентных клеток за исключением CD16+клеток. Абсолютное содержание NK-клеток у пострадавших второй подгруппы оставалось сниженным на $50,0 \%(p<0,05)$, т.е. оно было таким 
же, как во всех предыдущих случаях, когда исследовали кровь.

В таблице 2 представлены данные о функциональной активности лимфоцитов и нейтрофилов в периферической крови у пострадавших до операции и после операции в динамике.

Как видно из данных таблицы 2, у пострадавших до операции, а также при осложненном течении через 3 дня после операции имело место снижение функциональной активности Т-лимфоцитов на 47,0\% (p<0,05). Через 3 дня также у пострадавших с осложненным остеогенезом имело место снижение на 40,0\% ( $<0,05)$ активности В-лимфоцитов и увеличение в 2,2 раза $(\mathrm{p}<0,05)$ числа апоптотически измененных лимфоцитов.

У пострадавших с нормальным типом остеогенеза показатели Т- и В-клеточной активности были в пределах нормы. Уровень CD95+-клеток также был увеличен в 2,1 раза ( $<<0,05)$.

Через 3 месяца после операции у пациентов с нормальной консолидацией переломов все показатели CD25+, CD95+ и HLA DR+ были в пределах нормы. У пациентов с осложненным типом остеогенеза уровень CD95+-клеток оставался повышенным, превышая уровень контрольной группы людей на 57,1\% (p<0,05).

Таким образом, в раннем периоде травматической болезни при нормальном типе осте- огенеза изменения касались увеличения числа В-лимфоцитов при неизмененной их активности, а при осложненном типе - снижения числа и активности Т-клеток, особенно CD8+ и CD16+, a также снижения активности Т- и В-лимфоцитов. Величина апоптоза не влияла на тип течения остеогенеза. К моменту развития осложнений остеогенеза (через 3 месяца после операции) большинство показателей иммунитета восстанавливались. Сниженным оставалось число NKклеток и увеличенным число клеток с признаками апоптоза.

Как видно из данных этой таблицы, ФИ у пациентов двух подгрупп не изменялись ни относительно контроля, ни относительно друг друга. Показатель переваривающей способности нейтрофилов (ФЧ) у пациентов с осложненным течением был снижен по сравнению с контролем на 25,0\% (p<0,05). Этот же показатель у пациентов с нормальным типом остеогенеза был в пределах нормы. Через 3 месяца после операции все показатели фагоцитоза были в пределах нормы.

Показатели цитокинов и иммуноглобулинов класса A, G и М до операции и после представлены у пациентов 2-х групп в таблице 3 .

До операции в крови сохранялся высокий уровень ИЛ-1, ИЛ-2, Ил-4, ИЛ-6, ИЛ-8, ИЛ-10, ФНО- $\alpha$, а также концентрации Ig М. Это свиде-

Показатели гуморального иммунитета в периферической крови у пострадавших

Таблица 3. с нормальной и осложненной консолидацией переломов до и после операции $(\mathrm{M} \pm \mathrm{m})$

\begin{tabular}{|c|c|c|c|c|c|c|}
\hline \multirow{4}{*}{$\begin{array}{c}\text { Показате- } \\
\text { ли, ед. }\end{array}$} & \multirow{4}{*}{$\begin{array}{c}\text { Контроль } \\
(\mathrm{n}=15)\end{array}$} & \multicolumn{5}{|c|}{ По отношению к операции } \\
\hline & & \multirow{3}{*}{$\begin{array}{c}\text { до } \\
\text { операции }\end{array}$} & \multicolumn{4}{|c|}{ консолидация после операции } \\
\hline & & & \multicolumn{2}{|c|}{ через 3 дня } & \multicolumn{2}{|c|}{ через 3 месяца } \\
\hline & & & нормальная & осложненная & нормальная & осложненная \\
\hline ИЛ-1, пг/мл & $20,4 \pm 2,9$ & $63,5 \pm 2,9 *$ & $44,9 \pm 1,8 *$ & $66,7 \pm 1,5^{*}$ & $30,4 \pm 1,8$ & $39,9 \pm 1,2 *$ \\
\hline ИЛ-2, пг/мл & $13,2 \pm 1,4$ & $38,6 \pm 2,6^{*}$ & $41,6 \pm 2,0 *$ & $46,4 \pm 1,8^{*}$ & $18,6 \pm 0,2$ & $22,1 \pm 0,5^{*}$ \\
\hline ИЛ-4, пг/мл & $28,3 \pm 3,3$ & $58,7 \pm 2,2^{*}$ & $63,7 \pm 1,8^{*}$ & $72,4 \pm 3,6 *$ & $29,4 \pm 0,7$ & $25,9 \pm 1,6$ \\
\hline ИЛ-6, пг/мл & $14,9 \pm 3,4$ & $82,3 \pm 2,2 *$ & $94,4 \pm 2,7 *$ & $108,3 \pm 3,9^{*}$ & $16,9 \pm 1,1$ & $29,9 \pm 1,8 *$ \\
\hline ИЛ-8, пг/мл & $20,3 \pm 2,7$ & $63,9 \pm 1,7 *$ & $55,7 \pm 1,6^{*}$ & $88,9 \pm 2,3 *$ & $38,7 \pm 2,3 *$ & $40,5 \pm 2,2 *$ \\
\hline ИЛ-10, пг/мл & $6,4 \pm 0,9$ & $99,8 \pm 2,6 *$ & $79,6 \pm 2,4^{*}$ & $30,3 \pm 2,0^{*}$ & $8,1 \pm 0,99$ & $38,5 \pm 1,9 *$ \\
\hline ФНО- $\alpha$, пг/мл & $26,5 \pm 2,7$ & $64,6 \pm 2,0^{*}$ & $68,4 \pm 2,3 *$ & $110,7 \pm 3,4^{*}$ & $28,8 \pm 2,0$ & $88,4 \pm 3,3$ \\
\hline $\operatorname{Ig}$ A, г/л & $2,8 \pm 0,6$ & $2,3 \pm 0,1$ & $2,1 \pm 0,2$ & $2,6 \pm 0,3$ & $2,2 \pm 0,3$ & $2,6 \pm 0,3$ \\
\hline $\operatorname{Ig} \mathrm{G}$, г/л & $13,6 \pm 1,1$ & $13,9 \pm 1,2$ & $15,1 \pm 0,9$ & $13,0 \pm 0,9$ & $11,3 \pm 0,3$ & $14,4 \pm 0,6$ \\
\hline $\operatorname{Ig}$ M, г/л & $1,9 \pm 0,13$ & $2,7 \pm 0,15^{*}$ & $2,1 \pm 0,33$ & $2,6 \pm 0,17^{*}$ & $1,8 \pm 0,11$ & $2,0 \pm 0,17$ \\
\hline
\end{tabular}

Примечание: * - обозначена значимость различий по сравнению с контролем $(\mathrm{p}<0,05)$. 
тельствовало о напряженном иммунитете, воспалительной активации и о включении гуморального иммунитета в противомикробную защиту организма.

Через 3 дня после операции высокий уровень гиперцитокинемии сохранялся в обеих подгруппах пациентов, однако, у пострадавших с осложненным типом остеогенеза показатели провоспалительных цитокинов были больше, а противовоспалительных ИЛ-10 - ниже $(\mathrm{p}<0,05)$. Это указывало на то, что воспалительная реакция при нормальном типе регенерации костной ткани имела небольшую активность и продолжительность.

Через 3 месяца после оперативного вмешательства у пострадавших с нормальным типом остеогенеза все показатели цитокинов, за исключением ИЛ-8, снижались до уровня нормы. Это свидетельствовало о том, что репаративная регенерация кости завершилась, костная ткань сформировалась.

У пациентов с осложненным типом остеогенеза показатели цитокинов снижались по сравнению с предыдущими изменениями, но все-же уровень ИЛ-1 был на 95,6\% выше, чем в контроле (p<0,05), ИЛ-2 был выше на 67,7\% (p<0,05), ИЛ-6 - в два раза (p<0,05), ИЛ-8 - на 99\% ( $<<0,05)$, ИЛ10 - в 6 раз ( $<<0,05)$. Полученные данные свидетельствовали о незакончившейся стадии воспаления и оссификации, высокой роли гиперцитокинемии в развитии нарушений остеогенеза, т.е. замедления регенерации костной ткани. Увеличение концентрации Ig М при осложненном типе консолидации переломов указывал на

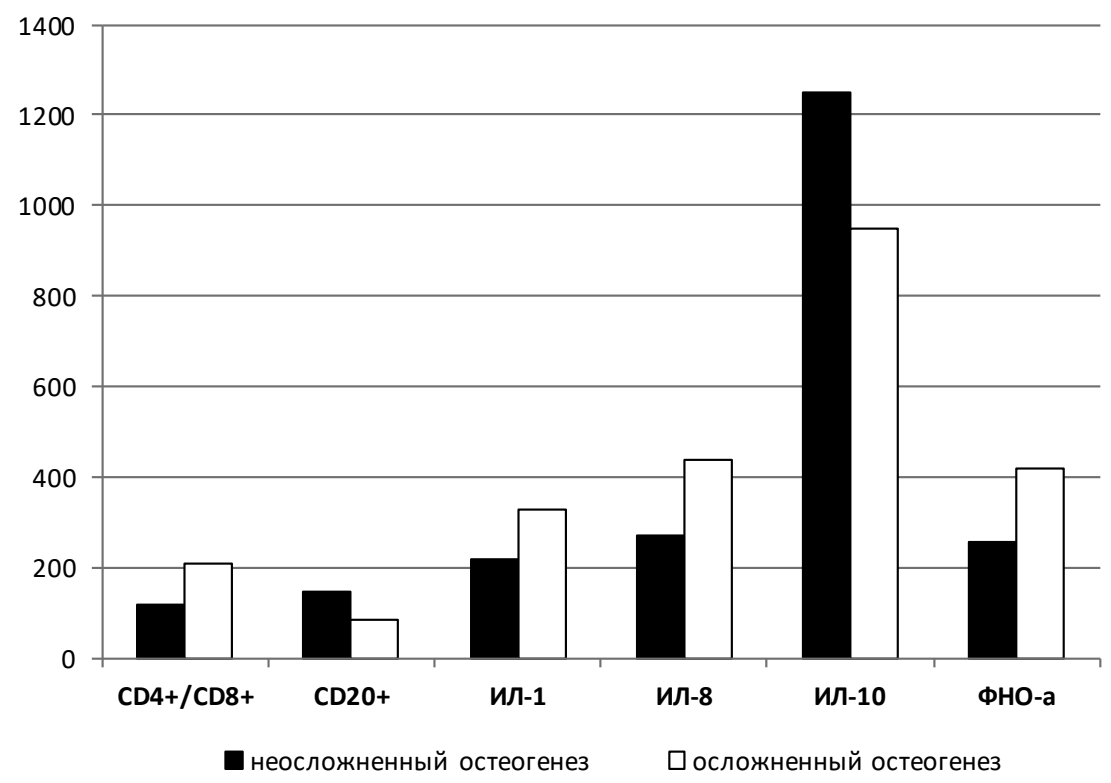

Рис. Показатели иммунологического статуса, достоверно различающиеся у пострадавших с неосложненным и осложненным остеогенезом в раннем периоде травматической болезни (\%). наличие новых для организма видов инфекционных возбудителей. У пациентов с нормальной консолидацией переломов либо к этим возбудителям уже был сформирован иммунитет, либо в более быстром темпе происходила перестройка несовершенного типа иммунного ответа (ответ Ig M) на совершенный (Ig G) тип.

Для более подробного изучения особенностей иммунологических нарушений в двух группах в раннем периоде травматической болезни мы сравнили между собой иммунологические показатели, полученные через 3 дня после операции. Результаты сравнения (в \%) представлены на рисунке.

Как видно из представленного рисунка, различались между собой 6 иммунологических показателей, два из которых относились к показателям клеточного иммунитета. Изменения иммунорегуляторного индекса указывали на нарушение соотношения двух субпопуляций лимфоцитов, т.е. более значимом снижении числа цитотоксических лимфоцитов, имеющих маркер CD8+. При таком снижении можно было ожидать, что в подгруппе пациентов с осложненным остеогенезом будет расти абсолютное число CD20+-лимфоцитов, поскольку CD8+-клетки способны подавлять продукцию В-лимфоцитов $[6,12]$. Однако, вопреки ожиданиям, биосинтез В-лимфоцитов не увеличивался, а наоборот, имел тенденцию к снижению. Такая дивергенция указывала на другие механизмы подавления продукции В-лимфоцитов.

Возможно, что иммуносупрессию В-лимфоцитов вызывало чрезмерное количество гормонов стресса - глюкокортикоидов $[6,11]$.

Различие в показателях цитокинов указывало на селективное повреждение костной ткани, о чем свидетельствовало увеличение концентрации провоспалительных цитокинов ИЛ-8, ФНО- $\alpha$, и в меньшей мере ИЛ-1, а также недостаточный уровень противовоспалительного цитокина ИЛ-10.

В пользу осложненного остеогенеза говорило увеличение иммунорегуляторного индекса $\geqslant 3,8$ ед., количества CD20+ $\leqslant 0,14 \times 109 /$ л, увеличение концентрации ИЛ-1 $\geqslant 66,74$ пг/мл, ИЛ-8 $\geqslant 88,91$ пг/ мл, ФНО- $\alpha \geqslant 88,4$ пг/мл и снижении концентрации ИЛ-10 60,32 пг/мл. 


\section{В Ы В О Д Ы}

1. Оценка изменений показателей клеточного, гуморального звеньев иммунитета и баланса цитокинов имеет существенное значение для понимания патогенеза раннего периода травматической болезни у раненых с огнестрельными переломами костей голени.

2. Для осложненного типа остеогенеза характерны выраженные нарушения функции иммунной системы уже в раннем периоде травматической болезни (через 3 дня после операции). Уровень $\mathrm{CD}^{+}$-клеток был снижен на 51,6\% (p<0,05),
$\mathrm{CD}^{+}$-клеток - на 64,1\% (p<0,05), CD16+-клеток на - 53,6\% (p<0,05). Активность Т-клеток была снижена на 47,0\% (p<0,05), HLA DR+-клеток на $33,3 \%(\mathrm{p}<0,05)$.

3. У пострадавших с нарушенным остеогенезом в раннем периоде травматической болезни значения ФЧ были снижены на 25,0\% (p<0,05), а также были зарегистрированы наибольшие значения в уровнях цитокинов, характеризующих активность воспалительных изменений в организме.

\section{А.А. Оприщенко ${ }^{1}$, С.Е. Золотухин ${ }^{1}$, Н.Н. Шпаченко ${ }^{1}$, А.А. Штутин ${ }^{1}$, И.В. Коктышев ${ }^{2}$}

${ }^{1}$ Республиканский травматологический центр, Донецик

${ }^{2}$ ГОО ВПО «Донецкий национальный медицинский университет имени М. Горького», Донецк

\section{ОСОБЕННОСТИ РАННИХ ИММУНОЛОГИЧЕСКИХ РЕАКЦИЙ ПРИ ОСЛОЖНЕННОМ ТЕЧЕНИИ ОГНЕСТРЕЛЬНЫХ ПЕРЕЛОМОВ ГОЛЕНИ}

Переломы голени преобладают в структуре огнестрельных переломов костей конечностей и характеризуются высоким уровнем осложнений.

Цель: изучение некоторых особенностей иммунного ответа в раннем периоде травматической болезни при осложненном течении огнестрельных переломов голени.

Материал и методы исследования. Проведено клинико-лабораторное обследование 83 раненых с огнестрельными переломами костей голени. Все раненые были мужчины, средний возраст $34,7 \pm 4,3$ года (20-48). Пулевые ранения имели место у 29 (34,9\%) пострадавших, взрывная травма - у $54(65,1 \%)$, в том числе осколочные - 47 (56,6\%), минно-взрывные - 7 (8,4\%). Изолированные повреждения - у 34 (40,9\%) раненых, множественные - 31 (37,4\%), сочетанные 18 (21,69\%). Открытые переломы IIIA типа (по классификации Gustilo-Andersen) - 34 (40,96\%), IIIB - 46 $(55,4 \%)$, IIIC - 3 (3,6\%).

На основании ретроспективного анализа материал был разделен на две группы: первая группа (n=53) - неосложненный характер раневого процесса и репаративного остеогенеза, вторая $(\mathrm{n}=30)$ - осложненный (развитие ранних или поздних местных раневых осложнений, нарушение консолидации переломов голени).
Результаты. Нарушение процесса остеогенеза ассоциировалось с наличием местных воспалительных осложнений. У пациентов 2 группы в остром периоде имело место снижение абсолютного количества CD3+-клеток (Т-лимфоцитов) - на 51,6\%, CD8+клеток - 64,1\% и CD16+-клеток - 64,1\%. Абсолютное число В-лимфоцитов не увеличивалось. Через 3 месяца у пациентов 2 группы показатели цитокинов оставались повышенными: ИЛ-1 - на 95,6\%, ИЛ-2 - 67,7\%, ИЛ-6 - в 2 раза, ИЛ-8 - на 99\%, ИЛ-10 - в 6 раз (р<0,05). В пользу осложненного остеогенеза говорило увеличение иммунорегуляторного индекса $\geqslant 3,8$ ед., количества CD20+ $\leqslant 0,14 \times 10^{9} /$ л, увеличение концентрации ИЛ-1 266,74 пг/мл, ИЛ-8 $\geqslant 88,91$ пг/мл, ФНО- $\alpha \geqslant 88,4$ пг/мл и снижение концентрации ИЛ- $10 \leqslant 60,32$ пг/мл.

Заключение. Установленные иммунологические изменения в раннем периоде травматической болезни являются предикторами осложнений огнестрельных переломов голени и могут быть использованы в качестве прогностических параметров и для коррекции лечебной тактики.

Ключевые слова: огнестрельные переломы голени, иммунные реакции, острый период, осложнения.

\section{A.A. Oprishchenko ${ }^{1}$, S.E. Zolotukhin ${ }^{1}$, N.N. Shpachenko ${ }^{1}$, A.A. Shutin ${ }^{1}$, I.V.Koktyshev ${ }^{2}$}

${ }^{1}$ Republican Trauma Center, Donetsk

${ }^{2} S E I$ HPE «M. Gorky Donetsk National Medical University», Donetsk

\section{PECULIARITIES OF EARLY IMMUNOLOGICAL REACTIONS WITH COMPLICATED COURSE OF GUNSHOT SHIN FRACTURES}

Fractures of the leg prevail in the structure of gunshot fractures of the bones of the extremities and are characterized by a high level of complications.

Purpose: to study some features of the immune re- sponse in the early period of traumatic disease in complicated gunshot fractures of the leg.

Material and methods. Clinical and laboratory examination of 83 wounded with gunshot fractures of the low- 
er leg bones was carried out. All the injured were men, average age was $34.7 \pm 4.3$ years [20-48]. Bullet injuries occurred in 29 (34.9\%) victims, explosive injuries - in 54 (65.1\%), including fragmentation - 47 (56.6\%), mine-explosive -7 (8.4\%). Isolated injuries - in 34 (40.9\%) of the wounded, multiple - 31 (37.4\%), combined - 18 (21.7\%). Open fractures of type IIIA (according to the Gustilo-Andersen classification) - 34 (40.9\%), IIIB - 46 (55.4\%), IIIC -3 (3.6\%).

Based on a retrospective analysis, the material was divided into two groups: the first group $(n=53)$ - the uncomplicated nature of the wound process and reparative osteogenesis, the second $(n=30)$ - complicated (development of early or late local wound complications, violation of consolidation of leg fractures).

Results. Disruption of the process of osteogenesis was associated with the presence of local inflammatory complications. In patients of group 2 in the acute period there was a decrease in the absolute number of CD3+ cells (T- lymphocytes) - by $51.6 \%$, CD8+ cells - $64.1 \%$ and CD $16+$ cells $-64.1 \%$. The absolute number of B-lymphocytes did not increase. After 3 months in patients of group 2, cytokine indices remained elevated: IL-1 - by $95.6 \%$, IL-2 - 67.7\%, IL-6 - 2 times, IL- 8 - by 99\%, IL-10 - 6 times (p $<0.05$ ). In favor of complicated osteogenesis there was an increase in the immunoregulatory index of $\geqslant 3.8$ units, the number of CD20 $+\leqslant 0.14109 / 1$, an increase in the concentration of IL- $1 \geqslant 66.74 \mathrm{pg} / \mathrm{ml}, \mathrm{IL}-8 \geqslant 88.91 \mathrm{pg} / \mathrm{ml}$, TNF- $\alpha \geqslant 88.4 \mathrm{pg} / \mathrm{ml}$ and a decrease in the concentration of IL- $10 \leqslant 60.32 \mathrm{pg} / \mathrm{ml}$.

Conclusion. The established immunological changes in the early period of a traumatic disease are predictors of complications of gunshot fractures of the leg and can be used as prognostic parameters for the correction of therapeutic tactics.

Key words: leg gunshot fractures, immune reactions, acute period, complications.

\section{ЛИТЕРАТУРА}

1. Гуманенко Е.К., Самохвалов И.М. Военно-полевая хирургия локальных войн и вооруженных конфликтов: Руководство для врачей. М.: ГЭОТАР-Медиа; 2011. 672.

2. Belmont P.J., Owens B.D., Schoenfeld A.J. Musculoskeletal Injuries in Iraq and Afghanistan: Epidemiology and Outcomes Following a Decade of War. J Am Acad Orthop Surg. 2016; 24 (6): 341-348. doi:10.5435/JAAOS-D-15-00123

3. Dougherty P.J, Najibi S., Silverton C., Vaidya R. Gunshot wounds: epidemiology, wound ballistics, and soft-tissue treatment. Instr. Course Lect. 2009; 58: 131-139.

4. Bartlett C.S., Helfet D.L., Hausman M.R., Strauss E. Ballistics and gunshot wounds: effects on musculoskeletal tissues. J Am Acad Orthop Surg. 2000; 8 (1): 21-36.

5. Rhee P.M., Moore E.E., Joseph B., Tang A., Pandit V., Vercruysse G. Gunshot wounds: A review of ballistics, bullets, weapons, and myths. J Trauma Acute Care Surg. 2016; 80 (6): 853-867. doi:10.1097/ PMID: 26982703

6. Политравма: травматическая болезнь, дисфункция иммунной системы, современная стратегия лечения. Под ред. Гуманенко Е.К., Козлова В.К. М.: ГЭОТАРМедиа; 2008. 608.

7. Manring M.M., Hawk A., Calhoun J.H., Andersen R.C. Treatment of war wounds: a historical review. Clinical orthopaedics and related research. 2009; 467 (8): 2168-2191.

8. Гуманенко Е.К., Бояринцев В.В., Супрун Т.Ю., Ляшедько П.П. Объективная оценка тяжести травм. СПб.: Воен.-мед.акад.; 1999. 110.

9. Gustilo R.B., Anderson J.T. Prevention of infection in the treatment of one thousand and twenty-five open fractures of long bones: retrospective and prospective analyses. J Bone Joint Surg Am. 1976; 58: 453-458.

10. Gustilo R.B., Mendoza R.M., Williams D.N. Problems in management of type III (severe) open fractures: a new classification of type III open fractures. J Trauma. 1984; 24: 742-746. doi: 10.1097/00005373-198408000-00009

11. Бурместер Г.Р., Пецутто А. Наглядная иммунология: пер. с англ., 3-е изд. М.: Бином; 2014. 320.

12. Савченко А.А., Борисов А.Г. Основы клинической иммунометаболомики. Новосибирск: Наука; 2012. 263.

13. Сарап П.В. Оптимизация иммунотропной терапии при ургентной хирургической патологии с учетом кластерной организации иммунной системы Дисс. на соиск. ученой степени доктора мед. Наук. Новосибирск; 2014. 364.

14. Хаитов Р.М. Иммунология: структура и функции иммунной системы. М.: ГЭОТАР-Медиа; 2013. 278.

\section{REFERENCES}

1. Gumanenko E.K., Samokhvalov I.M. Voenno-polevaya khirurgiya lokal'nykh voin i vooruzhennykh konfliktov: Rukovodstvo dlya vrachei. M.: GEOTAR-Media; 2011.672.

2. Belmont P.J., Owens B.D., Schoenfeld A.J. Musculoskeletal Injuries in Iraq and Afghanistan: Epidemiology and Outcomes Following a Decade of War. J Am Acad Orthop Surg. 2016; 24 (6): 341-348. doi:10.5435/JAAOS-D-15-00123

3. Dougherty P.J, Najibi S., Silverton C., Vaidya R. Gunshot wounds: epidemiology, wound ballistics, and soft-tissue treatment. Instr. Course Lect. 2009; 58: 131-139.

4. Bartlett C.S., Helfet D.L., Hausman M.R., Strauss E. Ballistics and gunshot wounds: effects on musculoskeletal tissues. J Am Acad Orthop Surg. 2000; 8 (1): 21-36.

5. Rhee P.M., Moore E.E., Joseph B., Tang A., Pandit V., Vercruysse G. Gunshot wounds: A review of ballistics, bullets, weapons, and myths. J Trauma Acute Care Surg. 2016; 80 (6): 853-867. doi:10.1097/ PMID: 26982703

6. Politravma: travmaticheskaya bolezn', disfunktsiya immunnoi sistemy, sovremennaya strategiya lecheniya. Pod red. Gumanenko E.K., Kozlova V.K. M.: GEOTAR-Media; 2008. 608.

7. Manring M.M., Hawk A., Calhoun J.H., Andersen R.C. Treatment of war wounds: a historical review. Clinical orthopaedics and related research. 2009; 467 (8): 2168-2191.

8. Gumanenko E.K., Boyarintsev V.V., Suprun T.Yu., Lyashed'ko P.P. Ob»ektivnaya otsenka tyazhesti travm. SPb.: Voen.-med.akad.; 1999. 110.

9. Gustilo R.B., Anderson J.T. Prevention of infection in the treatment of one thousand and twenty-five open fractures of long bones: retrospective and prospective analyses. J Bone Joint Surg Am. 1976; 58: 453-458.

10. Gustilo R.B., Mendoza R.M., Williams D.N. Problems in management of type III (severe) open fractures: a new classification of type III open fractures. J Trauma. 1984; 24: 742-746. doi: 10.1097/00005373-198408000-00009

11. Burmester G.R., Petsutto A. Naglyadnaya immunologiya: per. s angl., 3-e izd. M.: Binom; 2014. 320.

12. Savchenko A.A., Borisov A.G. Osnovy klinicheskoi immunometabolomiki. Novosibirsk: Nauka; 2012. 263.

13. Sarap P.V. Optimizatsiya immunotropnoi terapii pri urgentnoi khirurgicheskoi patologii s uchetom klasternoi organizatsii immunnoi sistemy Diss. na soisk. uchenoi stepeni doktora med. Nauk. Novosibirsk; 2014. 364.

14. Khaitov R.M. Immunologiya: struktura i funktsii immunnoi sistemy. M.: GEOTAR-Media; 2013. 278. 